\title{
Postmodern Chinoiserie in Gene Luen Yang's American Born Chinese
}

Philip Smith*

Loughborough University

\section{Abstract}

This paper offers a synthesis and critique of the existing academic literature on Gene Luen Yang's American Born Chinese and an overview of Asian American alternative comics. It examines the range of literary and linguistic sources which Yang draws upon in his collage of Chinoiserie and Japonism. It presents the argument that existing criticism has failed to take into account the rising presence of Asian and Asian American characters and creators in American comics.

Gene Luen Yang's American Born Chinese (2006) broke new ground for American comic books when it was shortlisted for a National Book Award. In 2006, the Publishers Weekly named it Best Comic of the Year and the San Francisco Chronicle named it Best Book of the Year. In 2007, it won the 2006/2007 Best Book Award from The Chinese American Librarians Association, the Amazon.com's Best Graphic Novel/Comic of the Year, the Michael L Prinz Award and the Eisner Award. Critics have celebrated American Born Chinese both as an educational tool (see Boatright 2010; Hammond 2012) and for its sophisticated dialogue on issues of race and identity.

American Born Chinese is the most celebrated text to date in a growing sub-genre of Asian American alternative comics (see Sabin $(1993,1996)$ and Hatfield (2005) for more on alternative comics). Other Asian American alternative comics include Yang's Gordon Yamamoto and the King of the Geeks (2004a), Loyola Chin and the San Peligran Order (2004b), Tak Toyoshima's Secret Asian Man (1999-2010), Adrian Tomine's Summer Blonde (2003), Derek Kirk Kim's Same Difference and Other Stories (2004) and Good as Lily (2007), Thien Pham's Sumo (2012), GB Tran's Vietnamerica (2011) and the collection Secret Identities: The Asian American Superhero Anthology (2009). I will argue that the Asian American alternative comics sub-genre, alongside the popularity of Japanese manga in America since the 1990s, and the increasing visibility of Asian and Asian American creators has coincided with (and perhaps contributed to) progressive depictions of Asians and Asian Americans in American comics. Yang's American Born Chinese embodies many of the progressive aspects of Asian American alternative comics by destabilising concepts of an undifferentiated Asian monoculture. It explores various historical and modern Asian cultures, Asian American identities, and the forms of racism which have been directed toward Asian Americans.

American Born Chinese draws upon a range of literary and linguistic sources. It blends pop culture with classical Chinese literature in a collage of Chinoiserie and Japonism. Yang references the 20th-century Japanese American animation both to provide a recurring metaphor for the text and to explore the multiplicity and cohesion of Asian American identities. He draws upon the 19th- and 20th-century American comics in his exploration of the history of racism toward Asians and Asian Americans. This paper will offer a synthesis and critique of the existing academic literature on American Born Chinese around these themes. It also continues the historical accounts offered by Fu (2007) and Gardner (2010) 
by contextualising American Born Chinese amongst modern portrayals of Asian and Asian Americans in American comics. ${ }^{1}$

\section{An Overview}

American Born Chinese is told in three intertwined storylines which ultimately resolve as one. The first is the story of the Monkey King, a retelling of the first seven chapters of the 16th-century Chinese literary classic Journey to the West. The Monkey King is excluded from a celestial dinner party on the grounds that he is a monkey. In his anger, he begins a reign of destruction against other heavenly beings. He is eventually imprisoned under a mountain by the deity Tze-Yo-Tzuh. He is released only when he accepts that he is a monkey, whereupon he joins the monk Lai-Tsao in his journey to the West. The story introduces the key themes of the text: the Monkey King becomes aware of his difference from others only when it is pointed out to him, and this difference causes a crisis in self-identity. He struggles to reinvent himself and eventually learns to embrace his identity.

The second story concerns Jin Wang, a second-generation Chinese American. Jin attends an almost entirely White school and is alienated because of his cultural background. Jin gains a friend when Wei-Chen, a student from Taiwan, joins the school. Jin becomes enamoured with a White classmate, Amelia, and, with Wei-Chen's help, he goes on a date with her. He feels that things went well until another classmate asks him not to see Amelia again. Enraged and embarrassed, Jin attempts to kiss Wei-Chen's girlfriend. His actions result in a broken friendship.

The third story concerns Danny, a White American whose life is ruined by annual visits from his Chinese cousin Chin-Kee. Chin-Kee is a synthesis of racist caricatures found in American media. He embarrasses Danny in front of his potential romantic partner, friends and classmates. Danny's patience with his cousin eventually reaches its limit, and, in a fit of rage, he assaults Chin-Kee.

The stories resolve as one. After his fight with Wei-Chen, Jin transforms into Danny. Chin-Kee reveals himself to be the Monkey King, who explains that Wei-Chen is his (The Monkey King's) son. The Monkey King advises Jin that 'I would have saved myself from five hundred years imprisonment beneath a mountain of rock had I only realised how good it is to be a monkey' (Yang 2006, 223). He leaves Jin with the address of a restaurant, where Jin meets with Wei-Chen once more. The two begin to repair their friendship.

\section{American Born Chinese and the (invisible) Asian in American Media}

Wei-Chen, Jin and the Monkey King are all afraid of having an identity thrust upon them, and all self-consciously construct their own identities. This preoccupation with the performance of Asian identities in America is concretised in Chin-Kee, who serves as a postmodern historiography of Asian and Asian American identities in comic books. The following section examines various critical responses to the quotations from American visual media which Yang employs.

Chin-Kee is a 'monstrously exaggerated concatenation of every popular cultural stereotype of Asian and Asian Americans over the last two centuries' (Gardner 2010, 139). He is an overt collage of hyperbolic Chinoiserie and racist caricature. He represents the many negative Asian identities which the characters will have thrust upon them if they do not actively and continually reinvent themselves. Several critics, most notably Song, Fu and Gardner, have taken Chin-Kee as a signal to examine the history of Asians and Asian Americans in American comics and have, with assistance from Yang via his blog, catalogued some of the genealogy of quotations which have informed the character. 
The stereotypes which Chin-Kee embodies are numerous and contradictory. He speaks broken English, and yet he knows specialised English terms (Smith 2013, online). These contradictory stereotypes reflect the many ways in which Chinese immigrants have been imagined in American popular culture. During the 19th-century newspaper, cartoons depicted the Chinese as animal-like and violent (see Fig. 3 and Choy et al.'s Coming Man (1994)). Early American newspapers such as The Wasp (1842-1843) featured racist caricatures of Asians in keeping with this mythology. These early cartoons depicted Chinese immigrants with slits for eyes, wearing coolie outfits and with ponytails. For Fu, Chin-Kee serves as 'an effective way to dispel the century-old image of the "Heathen Chinese", (Fu 2006, 276).

In the 1930s, detective comics featured 'Fu Manchu-like characters [who] represented the Chinese, and by extension, all Asian American men' (Dong 2011, 241). Examples include Smash Comics character Wun Cloo (Smith 2013, online), the recurring Marvel villain The Yellow Claw and the DC character Chop Chop (Yang 2008, online). These characters were more wily than their previous incarnations and some even occupied the role of the protagonist, but their caricatured features and coolie dress had changed little since the 1880s. Colour printing also expanded the cartoon language to include sallow skin as an Asian signifier. Yang appropriates this language for Chin-Kee and, to a lesser extent, for Jin (see Boatright 2010, 473). During World War II, racist depictions of Japanese soldiers in comic books shared a visual language with anti-Japanese propaganda posters (see Dong 2011, 243). These comics blended and confused all Asians under the generic stereotype of the Oriental man who, amongst other misdeeds, imprisons and sells women (see Fig. 1). ${ }^{2}$ Chin-Kee, in keeping with this mythology, drools over American women and wishes to bind their feet (Yang 2006, 50).

Crucially, such racist depictions of Asians and Asian Americans have relied upon concepts of an Asian monoculture, which Yang and his contemporaries have worked to dismantle.

Gardner contends that the 20th- and 21st-century stereotypes often depict Asian Americans as shy academic high-achievers. These stereotypes have roots in the 19th-century depictions of the Chinese (see Choy et al. (1994) for examples). Gardner describes modern depictions of

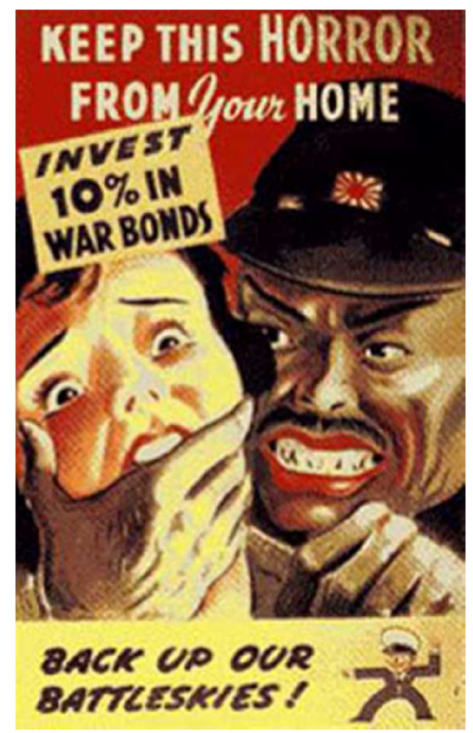

Fig. 1. World War 2 propaganda posters presented the Oriental man as a threat to women. The stylistics of the propaganda poster informed the portrayal of Asians in American comics. 
Asian Americans as 'mechanised alien robots' (Gardner 2010, 135). These stereotypes appear most often, he argues, in school newspapers. Yang's Chin-Kee embarrasses his cousin by knowing the answer to every question posed in class (Yang 2006, 111-113). The most disturbing aspect of Chin-Kee is his similarity to certain modern, and unironically racist, depictions of Asian Americans in political cartoons and televised media. The reference to 'Clispy fried cat gizzard' (Yang 2006, 114) quotes a 2001 editorial cartoon by Pat Oliphant (see Gardner 2010, 132). Chin-Kee's performance of 'She Bangs' references the performance by Asian American singer William Hung (see Fu 2007, 275; Vizzini 2007, online). One high schooler is afraid that Chin-Kee's spit will infect him with the SARS virus (Yang 2006, 202).

Of equal note is the relative invisibility of Asian characters in certain forms of American visual media. Hahne reads American Born Chinese in light of the casting decisions around The Last Airbender (2010). The film was based on the American cartoon series Avatar: The Last Airbender (2005-2008), a fantasy world which draws heavily upon Asian and Inuit mythology. The film remake featured an all-White main cast. Yang described the film as 'a white Asian fetishist's wet dream. All the Asian culture they want, without any of the Asian people' (quoted in Kim 2009, online). Yang wrote a short comic boycotting the film (see Fig. 2).

Hahne contends that, like the casting decisions of The Last Airbender which transformed a story drawn from Asian cultures into a story about White people, Jin/Danny, Wei-Chen and the Monkey King attempt to hide their identities. When Jin becomes Danny, he hides his Chinese heritage in order to have a social life. The Monkey King is haunted by the disdain of immortals and gods; he refuses his monkey nature and transforms himself into 'The Great Sage, Equal of Heaven'. At the end of the comic, Wei-Chen adopts a flamboyant style of dress which serves as an armour against racist caricatures. In all three cases, 'Yang's characters themselves attempt to bend their own race into something less offensive/more palatable to the racists who populate their daily environments' (Hahne nd. online).

$\mathrm{Fu}$ reads American Born Chinese as a challenge to the racist depiction of Asians and Asian Americans in comic books and to the invisibility of Asians in American media. The Monkey $\mathrm{King}$, for $\mathrm{Fu}$, offers a Chinese alternative to the superheroes who have dominated the pages of American comic books. Fu's argument is problematic given that the American comic book is a medium which has historically been used to explore the immigrant experience. Superman, the prototypical superhero, is an immigrant, having travelled from Krypton to Earth (see Dooley and Engle 1988). Like Stan Lee (Leiber), and Jack Kirby (Kurzberg), and like Jin/Danny, a recurring characteristic of the superhero genre is the second identity adopted by a hero in order to survive in American society. Indeed, in contrast to the largely negative vision of American comics sketched by Fu and Gardner, many modern American comics counter the racism of previous eras.

American Born Chinese is not the only work to disrupt concepts of an Asian monoculture, feature Asian American protagonists and explore the historical marginalisation of Asians and Asian Americans. Racist depictions of Asian American over-achievers in certain high school newspapers, the invisibility of Asians and Asian Americans in The Last Airbender and the racist cartoons of Pat Oliphant are not necessarily representative of modern American comics as a whole. The increasing visibility of Asian and Asian American characters in American comics has not been entirely absent from the literature on American Born Chinese to date, but the emphasis on the history of racism and, in Gardner's case, reliance upon too slim a sample of Asian American alternative comics threatens to present a far bleaker landscape than a wider view of the literature might reveal.

Since the 1990s, Japanese comic producers have aggressively targeted the American market with English-language translations of Japanese comics (see Brienza 2009). The majority of American comic book stores and book stores now include a section for manga. Translated manga provides an authentic insight into Japanese society, and many manga, such as the English-language version of the series Lone Wolf and Cub (2000-2003), include explanatory 

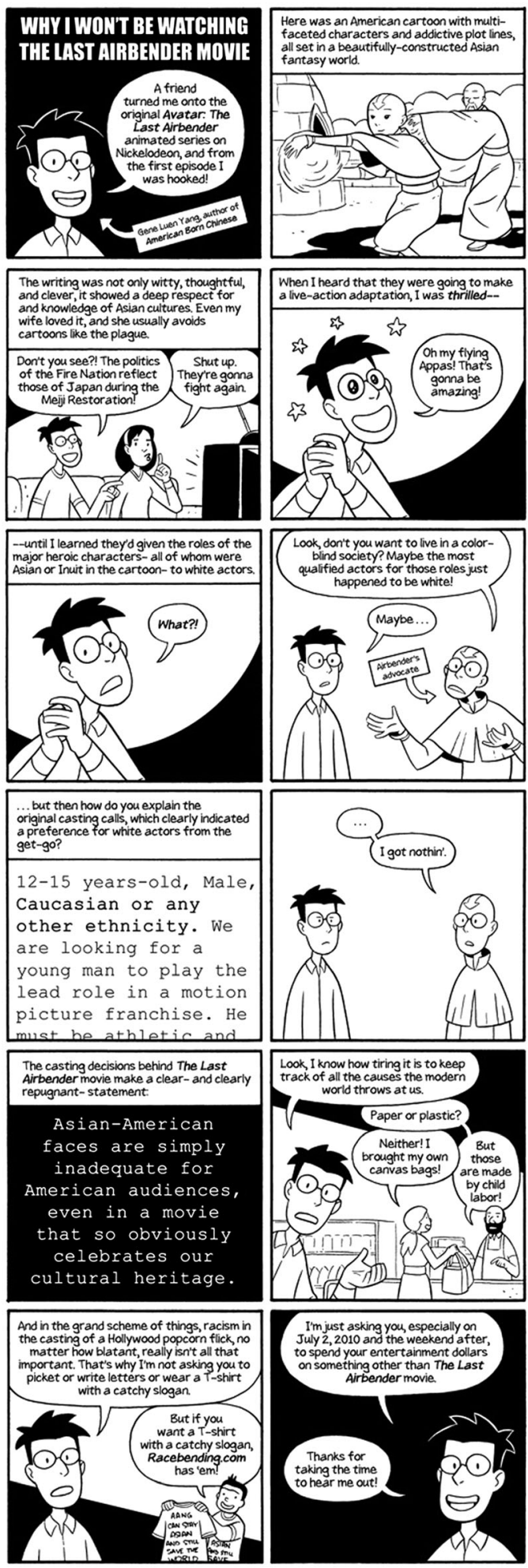

Fig. 2. Gene Luen Yang The Last Airbender Movie. 
essays on Japanese history and culture. The increasing availability of manga has inspired the genre 'AmeriManga' by American creators such as Fred Gallagher (see ANN 2002). AmeriManga comics are drawn by American creators using the visual conventions of Japanese manga. Gallagher's Megatokyo (2000-present) concerns the life of an American living in Tokyo and contains many references to Japanese culture and cross-cultural interactions. The influx of manga in the American market has served to destabilise racist concepts of a monolithic Asian culture and promote intercultural understanding.

The late 20th century has also seen an increase in the visibility and impact of Asian and Asian American comic book artists in both alternative and mainstream genres. In addition to those listed in the introduction of this paper, further examples of Asians and Asian Americans who write and draw comics include Christine Norrie, Jason Shiga, Jim Lee, Larry Hama and Sonny Liew. The growing presence of manga in the American comic book market and the increasing visibility of Asian and Asian American comic book creators has coincided with (and perhaps contributed to) changing portrayals of Asians and Asian Americans in American comics.

Asian American protagonists are still a minority compared to their White and African American counterparts but are appearing in increasing numbers in mainstream comics. To name just two examples, consider Jennifer Takeda ('Hazmat') in Marvel's Avengers Academy (2010-2012) and Avengers Arena (2012) and Glen in The Walking Dead (2003-present). ${ }^{3}$

Hazmat's saliva and sweat are radioactive. To keep her from poisoning others, she must wear an anti-radiation suit at all times. Her grandfather, like many Japanese Americans, was imprisoned in an internment camp during World War II (see Avengers Academy \#30). Hazmat represents an acknowledgement of the violence done to Japanese civilians, both at the sites of the atomic bombs and on American soil. The character literally embodies the ways in which that violence continues to shape the lives of Japanese Americans living today. Read in the context of American Born Chinese, her suit serves to physically alienate her from her fellow students and serves as a dramatisation of the same social exclusion which Jin/ Danny experiences at school. Hazmat's creator, Christos Gage, makes explicit the history of racism in American comics (see also Figs 3 and 4). In Avengers Academy \#22, Hazmat addresses Whiz Kid, a Japanese inventor and boy genius, as an 'Asian stereotype boy'.

Glenn was a long-running Korean American character in the hugely successful comic book series The Walking Dead. He engages in many heroic activities, including frequent missions in zombie-infested Atlanta to gather supplies for a group of survivors. He later marries Maggie Green, a White woman, making the pair a rare example in American media of an Asian male/White female interracial couple. When Glenn was killed off, a reader wrote:

Growing up an A[merican ]B[orn ]C[hinese], I didn't have many ethnic role models for myself in the American media. And this isn't to say that I believe Glenn was intended to be an ethnic role model. But that's exactly the point - his lack of obvious representation of a foreign ethnic group is in itself the most accurate portrayal I could ever have hoped for[...]He wasn't stereotypically "book smart” or “honourable." ('Adam' Walking Dead \#103)

Not every modern Asian comic book character avoids stereotypes. Knowledge of martial arts, particularly, remains a persistent myth. As with other media in America, Asian women get far more 'screen time' than Asian men. Hazmat and Glenn, however, both serve as examples of the ways in which many modern comic book writers are prepared to address the history of Asians living in America and to write against stereotypes.

Yang's work, as well as those of his contemporaries, can be understood as evidence of the growing visibility of Asian Americans in comics. Indeed, as shall now be discussed, Yang uses his medium as a means to explicitly challenge racist stereotypes. 


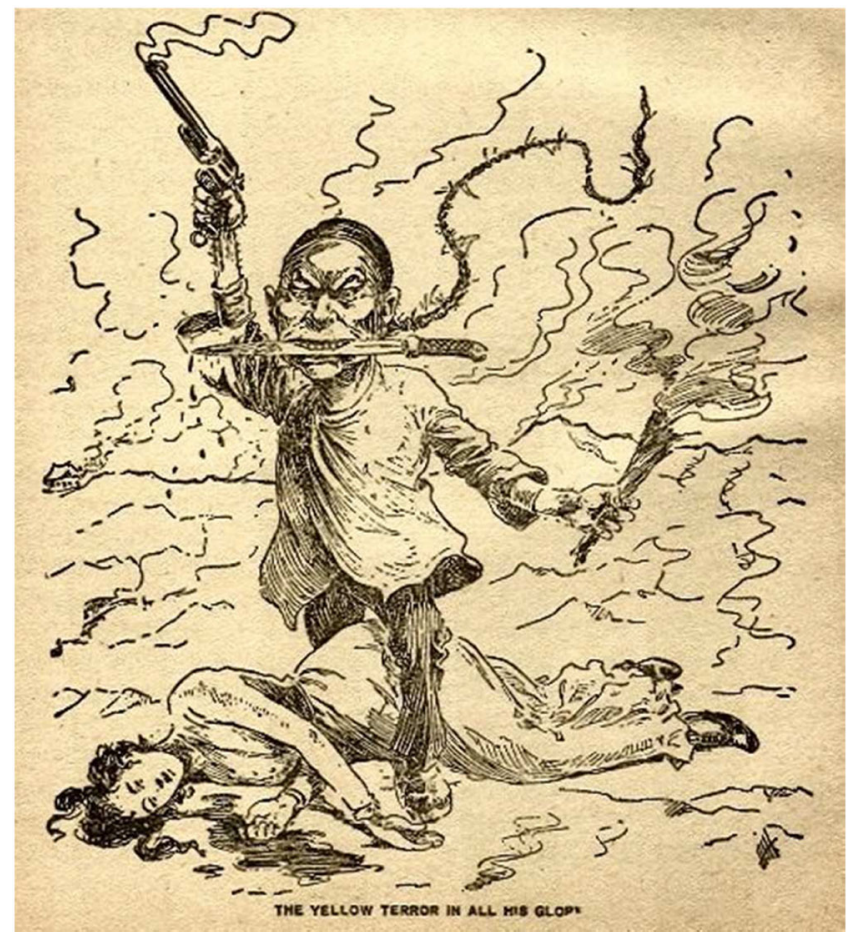

Fig. 3. 'The Yellow Terror in All His Glory' (1899).

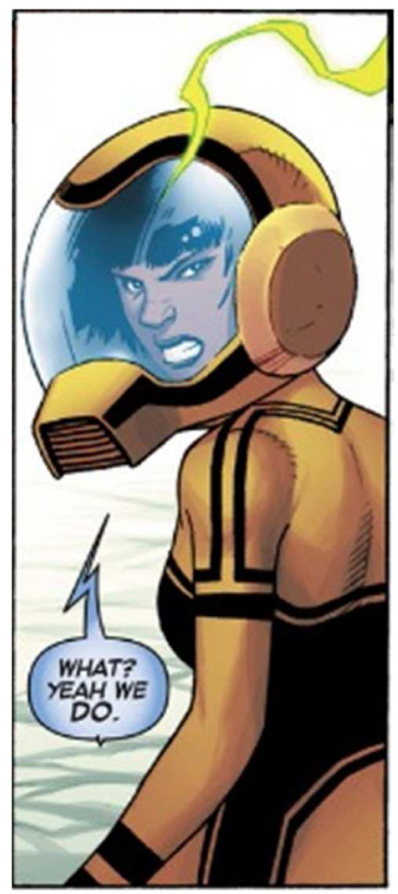

Fig. 4. The Marvel's Hazmat (c) 2013 Marvel. The depiction of Asian Americans in American comics has changed dramatically between the 19 th and 21 st centuries. 


\section{Postmodern Chinoiserie in American Born Chinese: A Journey to the West}

The most sustained reference in American Born Chinese is to the story of the Monkey King. The original Journey to the West is a mythical story of how Buddhism came to China from India. Dong asserts that Yang follows in the tradition of many American storytellers who have 'adapted or alluded to the story of the Monkey King and altered his character as well as the story line for their respective political and critical agendas' (Dong 2011, 234). Yang adapts the tale of the Monkey King not only into a story of self-discovery but also into a Judeo-Christian story. Tze-Yo-Tzuh, who imprisons the Monkey King, is Yang's creation and is more similar to an Abrahamic deity than any figure from Buddhist or Taoist traditions (Vizzini 2007, online). The story of Journey to the West, in Yang's telling, becomes the story of the Magi (the three kings) who bring gifts to the baby Jesus, signified by the shining star which the Monkey King and Lai-Tsao walk toward (Vizzini 2007, online). Yang has described Christianity as 'the world that I'm a little more familiar with' compared with Chinese religious traditions (Yang in Morton 2010, online). ${ }^{4}$ Yang's blend of Chinese and Western mythologies fuses cultural codes and introduces the theme of transformation into the text. It also serves to destabilise concepts of a monolithic Asian culture by providing an introduction to Chinese mythology. Yang uses these references to distinguish between historical Chinese culture and modern Asian American identities.

In my essay published on Comics Forum, I read the comic as a means of creating a Chinese/ English hybrid literary form which can offer a bridge between the Asian American experience and other American cultures. I contend that Yang uses English with 'fragments of unassimilated and authenticated Asian language' in both the untranslated traditional Chinese characters spoken by the Monkey King and the Chinese-cadenced English spoken by Wei-Chen and Chin-Kee (Smith 2013, online). I argue that the use of untranslated traditional Chinese characters serves to other Chinese language. Yang presents Chinese script as the language of what Fu calls 'oriental magic'; the characters speak Chinese characters in order to activate their magical powers (Fu 2006, 275). The relationship between American English and Chinese script mirrors the relationship between Jin/Danny and his parent's culture. Both Dong and I argue that Jin/Danny (who speaks Mandarin but struggles to read Chinese script) should be read as a relative outsider in relation to China's literary history:

Jin has no means to represent modern China or the postmemory of the Cultural Revolution, just a myriad of imagined Chinas drawn primarily from the American cultural imagination. Jin is only Chinese in relation to the non-Chinese characters (Smith 2013, online).

Dong similarly contends that "by choosing the term "American Born Chinese" instead of the more inclusive and commonly used "American Chinese," Yang draws a distinction between the American-born generation and their immigrant parents' (Dong 2011, 232). The balance between Chinese and American visual and linguistic forms is not equal. In an American context, the Chinese characters (in both senses of the term) are filtered through the (Asian) American cultural imagination.

Yang further communicates Jin/Danny's relationship to his Chinese ancestry through puns in Mandarin. Doughty contends that Chin-Kee's name doubles as both the English-language racial slur 'Chinky' and a combination of the character 亲'relative' and the English word 'key'. ChinKee (or '亲-key') is a counterpart to Danny, whose name in Mandarin sounds like 大你'big you' or 打你'strike you' (Doughty 2010, 56-57). Doughty reads this doubled language as a dramatisation of the internal struggle between Jin/Danny's Chinese and American racialised identities. Chin-Kee, the Chinese blood relative, is the key who can unlock Danny and transform him back into Jin. The repeated strikes which Chin-Kee delivers to Danny's face (and Wei-Chen delivers to Jin's face) represents Jin's internal struggle to come to terms with 
his own racial identity. Doughty's analysis omits the usual rendering of the English name Danny into Chinese 大内'big inside/within'. Beneath Danny's seemingly unremarkable White face is a chaotic internal world. On the surface, he appears to be a member of America's racial and religious majority, but on the inside, he struggles to reconcile his American and Chinese identities.

\section{More than Meets the Eye}

Jin/Danny's relative unfamiliarity with traditional Chinese language does not prevent him from engaging with modern Asian and Asian American culture. Both Jin and Wei-Chen own Transformer toys. The Transformer brand was originally designed by the American company Hasbro and the Japanese company Takar Tomy. Transformers are robots which can change into vehicles, dinosaurs or other objects (examples include a cassette player). In the Transformers television series (1984-2012), comic books (1984-present) and films (animated 1986-1998, live action 2007-2011), the Autobots, the heroic protagonists, arrive in America to do battle with their enemies the Decepticons and to secure the fuel they need to return home. The Transformers are biracial in the sense that they are the result of an American-Japanese partnership. They are also, like Superman, immigrants to Earth, having been displaced from their home planet, Cybertron. The Transformers can hide their true nature and become unremarkable in their new home.

The Transformer is a metaphor which runs throughout American Born Chinese. All of the main characters are, to borrow the tagline from the first series of Transformers, 'more than meets the eye'. Jin is Danny. Chin-Kee's antics force him to transform back. Wei-Chen is a monkey who has transformed into a human. Yang makes the allusion explicit when Wei-Chen's father, the Monkey King, gives him a Transformer toy 'to remind you of who you are' (Yang 2006, 217). For Fu, the Monkey King himself is the most intriguing transformer. Not only does the Monkey King use his magical powers to transform his appearance throughout the text but also Yang transforms The Monkey King's story, as noted above, into a Christianised journey toward self-acceptance which parallels Jin/Danny's transformation. The Monkey King's story is also a literal journey to the West. He begins in mythical China and travels to America (rather than beginning in India and travelling to China in the original Journey to the West) where he transforms once more into Chin-Kee, the embodiment of Danny's otherwise marginalised Chinese American identity.

\section{Asian (American) Identities}

Yang's reference to Transformers (a modern Japanese/American mythology) in a story with a Chinese American protagonist is far from straightforward. When Jin arrives at Mayflower Elementary School (a reference, Dong contends, to the Mayflower pilgrim settlement in 1620), he meets Japanese American classmate Suzy Nakamura. Despite differences in language and culture, and a history of tension between Japan and China, Jin's classmates initially assume that the two are related and, later, that they are engaged to be married. As a result, Jin and Suzy spend much of their early years avoiding one another.

In recognition of the multiple Asian identities in America, Doughty reads American Born Chinese as a dramatisation of tensions between certain groups in Taiwan and mainland China over Taiwan's political status. When the teacher tells the class that Wei-Chen is from China, he asserts that he is from Taiwan. The scene doubles the panel in which Jin is introduced to the class and corrects the teacher by asserting that he is from San Francisco, not China. Jin feels an immediate and inexplicable desire to bully Wei-Chen when they first meet. Jin's instant dislike of Wei-Chen reflects both his racial self-hatred and the question, Doughty contends, of Taiwan's political status. Like every other Asian identity in the text, Wei-Chen's Taiwanese identity is not fixed. After Jin makes a failed attempt to kiss Suzy, Wei-Chen's anger is 
exacerbated by his belief that he and Jin are family. The scene, Doughty contends, reverses the argument often made by certain voices in mainland China that the majority of people who reside in Taiwan and mainland China share a common ancestry.

Before Jin and Wei-Chen's friendship falls apart, Wei-Chen and Suzy start dating, and the three form a friendship group. Their classmates use their (Suzy, Jin and Wei-Chen's) shared Asian American identity as a weapon against them. A passing classmate tells another that he is getting 'gook bumps' referencing a racial slur used, most famously, by American soldiers to refer to the Vietnamese (Yang 2006, 96). By taking on a single Asian American identity, Jin, Wei-Chen and Suzy automatically assume every Asian signifier in the eyes of their peers.

Alongside the many Asian nationalities which appear in the text, Yang explores many specifically Asian American identities. The timing of Chin-Kee's arrival is noteworthy. He enters the text just as Danny is becoming close with his White friend Melanie. Doughty contends that ' $[\mathrm{t}]$ he effect is immediate and unmistakable: While chauvinistic and lustful on one hand, the Asian male is simultaneously found lacking any substantive masculinity on the other' (Doughty 2010, 57). The insistence of the weak Asian male identity which Chin-Kee forces upon Danny is paralleled by Wei-Chen's over-performed masculine identity at the end of the book. Song views Wei-Chen's new identity as membership into the distinctively Asian American Japanese import street racing scene which is a means to assert Asian masculinity in an Asian American context. The identity he has adopted is a necessary protection against racist images which imagine Asians as subhuman.

Song's interpretation of Wei-Chen's final identity is not universally accepted. How we understand Wei-Chen's final transformation sits at the heart of the book's moral message, and yet critics seem divided over exactly what identity he has adopted. In contrast to Song, I read Wei-Chen's transformation as taike, a specifically Taiwanese style of excessive dress (Smith 2013, online). Wei-Chen adopts a deliberately non-American Asian identity. His street racer/taike identity is supported by his refusal to speak in English. Cheney contends that Wei-Chen takes on the trappings of American Hip Hop culture and thus a style of dress which is more commonly associated with certain African American, rather than Asian American, cultures. Cheney asserts that Wei-Chen's Hip Hop accessories serve to emphasise the degree to which his identity is a performance. The monkey which Jin Wang sees, Cheney contends, serves as a medium through which Jin Wang and Wei-Chen recognise their shared identity.

\section{The American Comic Book vs. Racism}

Gardner contends that much of the calculated racism toward Asians in American which Jin and his friends experience originated in single-panel comics such as those which appeared in The Wasp. He argues that, in the case of multi-panel comics, 'comics have a unique and contrasting ability to destabilize racial stereotypes [...] because of the ellipses and lacunae at the heart of the comics form [racist] arguments always are at risk of going astray' (Gardner 2010, 135-139). Comic books are, he asserts, able to collapse and work through racist stereotypes. In the portrayal of Chin-Kee, Gardner contends, Yang employs a range of stereotypes of in order to implode them.

Gardner's arguments appear to support the central argument of this essay that American Born Chinese is the exemplary text of the many (post)modern American comics which challenge racist depictions of Asians and Asian Americans. Gardner somewhat overstates his case, however, when he claims that 'comics make impossible [...] unequivocal meanings, and a stable definition of us and them' (Gardner 2010,142) and that 'the sequential comic is the most powerful [...] medium for embracing the radical consequences of an alterity that 
disables stereotypes and easy readings of the hegemonic gaze' (Gardner 2010, 147). If understood as a totalising statement, it is hard to reconcile Gardner's argument with images of Captain America doing battle with Middle Eastern terrorists in the Enemy arc (Cassaday and Rieber 2002a), a fight which is clearly founded upon concepts of 'us and them' and supported with racist cartoon language. It is also hard to make a case that second-generation Shoah survivor Art Spiegelman's satirical entries for the 2002 Iranian Anti-Semitic cartoon competition fail to complicate racist editorial cartoons because he uses single static images rather than a series of static images (see Spiegelman 2011, 102-103).

It is unclear in Gardner's argument how postmodern collage of ironic quotations from racist comics alone serves to destabilise those caricatures (other than, perhaps, to make the modern educated reader uncomfortable). This question is particularly important when one considers that America Born Chinese is typically considered to be a children's book. The irony of Yang's postmodern play with older literary forms may be lost on a readership who have had little exposure to the works he references. A younger audience might read Chin-Kee as an unironic depiction of mainland Chinese (see Dong 2011, 241). One might suggest that progressive depictions of Asian Americans (such as The Walking Dead's Glenn) serve as a better means to dismantle the racist caricatures established by previous generations of comic book writers.

Rather than reading Chin-Kee as a process of dismantling the uncomfortable history of Asian identities in American cartoons through narrative and hyperbole, his presence might better be understood as an allegory for the persistence and damaging effects of such stereotypes. Chin-Kee's presence in Danny's life (and in the text as a whole) illustrates the damage which these stereotypes wreak in the lives of Asian Americans. For Fu and Vizzini, it is the racism of the White characters which is most deserving of attention: ' $[\mathrm{m}]$ ore disquieting than Chin-Kee himself is the reaction of his American peers. They accept him with blank, idealized political correctness.' (Vizzini 2007, online). The most harmful violence depicted in the text is not the exaggerated racist caricature Chin-Kee but Danny's classmates who make squinty eyes at when the Asian characters look away. Dong asserts that ' $[\mathrm{t}]$ he very first morning, though well intentioned, [Jin's] teacher mispronounces his name, misidentifies his origin, and promotes stereotypes about people of Chinese heritage' (Dong 2011, 238). The Asian American characters arrange their identities around this racism. Danny, Davis argues, is 'haunted by the (literal) spectre of the Asian stereotype' (Davis 2011, 280). American Born Chinese alerts readers to the ways in which racism has become something performed in whispers to one side or hidden behind a veneer of political correctness and betrayed by slips of speech. The damage of such stereotypes is not that they are used as a weapon against ethnic minorities but that they may be internalised by members of those groups. Jin, Davis argues, 'is a victim of the pervasiveness of racial stereotypes; he suffers from the consequences of their existence at the same time that he accepts them' (Davis 2011, 280). Yang's American Born Chinese, alongside the works of his contemporaries, serves as a means to challenge and exorcise the now subtle racism toward Asians and Asian Americans.

\section{Conclusion and Future Research}

In American Born Chinese, Yang offers a postmodern critique of Asian and Asian American stereotypes. He sensitises the reader to subtle forms of racism at work in American society. He challenges concepts of a monolithic Asian culture and invites readers to consider the various cultural forces which create and proliferate stereotypes. In doing so, he joins with other voices working in American comics which seek to reinvent Asian American identities in American media. 
For a text which is, at the time of writing, just seven years old, American Born Chinese has already enjoyed a great deal of critical attention. Only Song, however, has made any attempt to challenge Yang's moral. She argues that Yang's celebration of race pride avoids and replaces issues around class. One might argue that Yang's simplistic message (that Asian Americans should accept who they are) fails to match the brilliance of his postmodern historiography of Asian and Asian American identities. In defiance of his moral, Yang makes clear that, for Asian Americans, the issue of 'who you are' is in a state of constant reinvention. Future analysis may challenge and celebrate Yang's message. ${ }^{5}$

The existing scholarship on American Born Chinese signals a need for greater recognition of the growing visibility of Asian characters in contemporary comic books and other American media. The examples given throughout this essay are far from exhaustive. Future scholars may consider the Singaporean superhero Jenny Quantum of the Wildstorm Universe and European comic books such as Glyn Dillon's The Nao of Brown (2012). The exorcism of the 'coolie' and the 'yellow peril' from modern American popular culture is still a work in progress, but some hope exists. Comic book creators are increasingly sensitive to the damaging effect of stereotypes, and many are involved in actively reinventing the role of Asians and Asian Americans in American media.

\section{Short Biography}

Philip Smith teaches English Literature at Sekolah Tunas Muda, Jakarta. He is in his final year of PhD studies with Loughborough University and has authored several articles in the fields of English Literature and Comic Book Studies. He is a co-editor of Scarecrow Press' forthcoming book Joss Whedon's Firefly.

\footnotetext{
Notes

* Correspondence: English \& Drama, Loughborough University, Epinal Way, Loughborough, Leicestershire, UK. Email: philipsmithgraduate@gmail.com

1 This paper will only consider the literary analysis of American Born Chinese and, as such, will not engage in a detailed analysis of the work of scholars such as Boatright (2010) and Hammond (2012), who read American Born Chinese in terms of its use in the classroom.

2 Rana Kabanni contends that in Western art and literature, the Asian female body has historically been depicted in need of rescue from her male counterpart:
}

The villainy of Oriental men is aggravated by the fact that they are portrayed as traders in female bodies[...] This idea was highly important in distinguishing between the barbarity of the Eastern male and the civilised behaviour of the Western male. One tied women up and sold them at slave auctions; the other revered them and placed them on pedestals. (Kabanni 1986, 79)

\footnotetext{
These images have historically served to legitimise colonial rhetoric, inspire of Asian men, and, in the context of World War II comics, to cast the American soldiers in the role of heroes and saviours.

3 The hero who first did battle with the Yellow Claw was not a White man but Jimmy Woo, a character who continues to appear in Marvel comics. Early appearances by Jimmy Woo are, by modern standards, still problematic, but Marvel's decision to lead with an Asian hero was unusual for the time in any popular American medium.

${ }^{4}$ The blend of Chinese mythical history with Western spirituality is to be repeated in Yang's Boxers E Saints (2013), which tells the story of China's 1900 Boxer Rebellion in one volume and the story of a young woman's conversion to Catholicism in the second.

5 Future research might also expand upon Cheney's aside which draws a connection between the Monkey King and Henry Louis Gates Jr.'s work on the Signifyin(g) Monkey. Critics may read Chin-Kee's repetition of racist caricatures as a double-voiced occupation of a White sign. Gardner and Dong both come close to such a reading without drawing explicitly from Gates' critical terminology.
} 


\section{Works Cited}

'Adam'. Letter Hack. Kirkman, Robert, Adlard, Charlie and Rathburn, Cliff. The Walking Dead \#103. 2012.

Anonymous. 'I.C. Promotes AmeriManga'. ANN. [Online]. Retrieved on 27 November 2002.

Boatright, Michael D. 'Graphic Journeys: Graphic Novels' Representations of Immigrant Experiences.' Journal of Adolescent and Adult Literacy 53.6 (2010): 468-76.

Brienza, Casey E. 'Books, Not Comics: Publishing Fields, Globalization, and Japanese Manga in the United States.' Publishing Research Quarterly 25(2) (2009): 101-17.

Cassaday, J. and J. N. d. Rieber. 'Enemy Chapter One: Dust.' Captain America \#1. Marvel Comics, 2002a.

—. 'Enemy Chapter Two: One Nation.' From Captain America \#2. Marvel Comics, 2002b.

— . 'Enemy Chapter Three: Soft Targets.' From Captain America \#3. Marvel Comics, 2002c.

—. 'Untitled.' From Captain America \#4 Marvel Comics, 2002d.

—. 'Untitled.' From Captain America \# 5 Marvel Comics, 2002e.

Chow, Keith, et al. Secret Identities: The Asian American Superhero Anthology. New York: The New Press, 2009.

Choy, Philip P., Lorraine Dong, and Marlon K. Hom. The Coming Man: Nineteenth Century American Perceptions of the Chinese. Seattle: University of Washington Press, 1994.

Davis, Rocío G. 'American Born Chinese: Challenging the Stereotype.' Graphic Subjects: Critical Essays on Autobiography and Graphic Novels. Ed. and introd. Michael A. Chaney. Madison, WI: U of Wisconsin, 2011. 279-81.

Dillon, Glyn. 'The Nao of Brown.' SelfMadeHero, 2012.

Di, Martino, Michael Dante, and Bryan Konietzko. Avatar The Last Airbender. Nickelodeon, 2005-2008.

Dong, Lan. 'Reimagining the Monkey King in Comics: Gene Luen Yang's American Born Chinese.' The Oxford Handbook of Children's Literature. Eds. Julia L. Mickenberg and Lynne Vallone. Oxford: Oxford University Press, 2011. 231-51.

Dooley, Dennis and Gary Engle. Superman at Fifty. New York: Collier Books, 1988.

Doughty, Jonathan. 'More than Meets the 'I': Chinese Transnationality in Gene Luen Yang's American Born Chinese.' Asian American Literature: Discourse \& Pedagogies. San Jose: San Jose State University, 2010. 54-60.

$\mathrm{Fu}$, Binbin. 'Review of American Born Chinese.' MELUS 32.3 (2007): 274-6.

Gage, Christos and Mike McKone. 'Avengers Academy \#30.' Marvel Comics, 2010a.

- 'Avengers Academy \#22.' Marvel Comics, 2010b.

Gardner, Jared. 'Same Difference: Graphic Alterity in the Work of Gene Luen Yang, Adrian Tomine, and Derek Kirk Kim.' Multicultural Comics: from "Zap" to "Blue Beetle". Austin, TX: University of Texas Press, 2010. 132-47.

Gates Jr., Henry Louis. The Signifying Monkey. Oxford: Oxford University Press, 1988.

Hahne, Seth T. 'American Born Chinese'. Good Ok Bad, no date. [Online].

Hammond, Heidi. 'Graphic Novels and Multi-modal Literature: A High School Study with American Born Chinese.' Bookbird: A Journal of International Children's Literature 50.4 (2012): 22-32.

Hatfield, Charles. Alternative Comics: An Emerging Literature. Mississippi: University of Mississippi Press, 2005.

Kim, Derek Kirk. Good as Lily. New York: Top Shelf Productions, 2007.

—. 'New Day in Politics, Same Old Racist World on the Silver Screen.' [Online]. Retrieved on 20 Jan 2009 from: Lowbright.com.

- Same Difference and Other Stories. New York: Top Shelf Productions, 2004.

Kioke, Kazuo and Goseki Kojima. Lone Wolf and Cub. volumes 1-28. Milwake, Oregon: Dark Horse, 2000-2003.

Morton, Paul. 'The Millions Interview: Gene Luen Yang.' The Millions. [Online]. Retrieved on 8 Jul 2010.

Norrie, Christine. Cheat. Portland: Oni Press, 2003.

Rana, Kabanni. Europe's Myths of Orient. Indiana: Indiana University Press, 1986.

Sabin, Roger. Adult Comics: An Introduction. Florence, Kentucky: Routledge, 1993.

- Comics, Comix and Graphic Novels: A History of Comic Art. London: Phaidon, 1996.

Shiga, Jason. Bookhunter. Portland: Sparkplug Comics, 2007.

Shyamalan, M. Night dir. The Last Airbender. 2010.

Smith, Philip. 'Hybrid Languages and Literary Forms in Gene Luen Yang's American Born Chinese.' Comics Forum.

[Online]. Retrieved on 9 May 2013.

Song, Min Hyoung. "'How Good It Is to Be a Monkey": Comics, Racial Formation, and American Born Chinese.'

Mosaic: A Journal for the Interdisciplinary Study of Literature 43.1 (2010): 132-47.

Spiegelman, Art. Metamaus. New York: Pantheon, 2011.

Thien Pham. Sumo. New York: First Second, 2012.

Tomine, Adrian. Summer Blonde. Montreal: Drawn and Quarterly, 2003.

Toyoshima, Tak. Secret Asian Man. 1999-2010. [Online].

Tran, G. B. Vietnamerica. New York: Villard, 2011.

Vizzini, Ned. 'High Anxiety.' The New York Times 13 May 2007. [Online].

Yang, Gene Luen. American Born Chinese. New York: First Second, 2006.

_ . 'Chop Chop'. The Blog of Gene Luen Yang. [Online]. Retrieved on 12 Feb 2008. 
Gordon Yamamoto and the King of the Geeks. San Jose: SLG Publishing, 2004a.

Loyola Chin and the San Peligran Order. San Jose: SLG Publishing, 2004b.

'The Last Airbender Movie'. The Blog of Gene Luen Yang. [Online]. Retrieved on 24 May 2010.

Boxers and Saints. New York: First Second, 2013. 